\title{
Chemical composition and in vitro inhibitory effects of essential oils from fruit peel of three Citrus species and limonene on mycelial growth of Sclerotinia sclerotiorum
}

\author{
A. L. B. Dias ${ }^{a}$ (D), W. C. Sousa ${ }^{a}$ (D) H. R. F. Batista ${ }^{a}$ (D), C. C. F. Alves ${ }^{a}$ (D), E. L. Souchie ${ }^{a}$ (D), \\ F. G. Silva ${ }^{a}$ D, P. S. Pereira ${ }^{a}$ \\ D, E. M. Sperandio ${ }^{a}$ (D), C.M. Cazal \\ (D), M. R. Forim ${ }^{c}$ \\ and M. L. D. Miranda ${ }^{d^{*}}$
}

anstituto Federal de Educação, Ciência e Tecnologia Goiano, Campus Rio Verde, Rod. Sul Goiana, Km 01, CEP 75901-970, Rio Verde, GO, Brasil

'Instituto Federal de Educação, Ciência e Tecnologia do Sudeste de Minas, Campus Barbacena, Rua Monsenhor José Augusto, 204, São José, CEP 36205-018, Barbacena, MG, Brasil

'Departamento de Química, Universidade Federal de São Carlos, Rodovia Washington Luis, Km 235, CEP 13565-905, São Carlos, SP, Brasil

'Instituto Federal de Educação, Ciência e Tecnologia do Triângulo Mineiro, Campus Uberlândia Centro, Rua Blanche Galassi, Morada da Colina, Centro, CEP 38411-104, Uberlândia, MG, Brasil

*e-mail: maykermiranda@iftm.edu.br

Received: November 24, 2018 - Accepted: February 07, 2019 - Distributed: May 31, 2020

(With 1 figure)

\begin{abstract}
Essential oils (EO) from aromatic and medicinal plants generally perform a diverse range of biological activities because they have several active constituents that work in different mechanisms of action. EO from Citrus peel have an impressive range of food and medicinal uses, besides other applications. EO from Citrus reticulata, C. sinensis and C. deliciosa were extracted from fruit peel and analyzed by GC-MS. The major constituent of EO under evaluation was limonene, whose concentrations were $98.54 \%, 91.65 \%$ and $91.27 \%$ for C. sinensis, C. reticulata and C. deliciosa, respectively. The highest potential of inhibition of mycelial growth was observed when the oil dose was $300 \mu \mathrm{L}$. Citrus oils inhibited fungus growth in $82.91 \%$ (C. deliciosa), 65.82\% (C. sinensis) and $63.46 \%$ (C. reticulata). Anti-Sclerotinia sclerotiorum activity of $90 \%$ pure limonene and at different doses $(20,50,100,200$ and $300 \mu \mathrm{L})$ was also investigated. This monoterpene showed to be highly active by inhibiting $100 \%$ fungus growth even at 200 and $300 \mu \mathrm{L}$ doses. This is the first report of the in vitro inhibitory effect of natural products from these three Citrus species and its results show that there is good prospect of using them experimentally to control S. sclerotiorum, in both greenhouse and field conditions.
\end{abstract}

Keywords: Citrus reticulata, Citrus sinensis, Citrus deliciosa, white rot, limonene, white mold.

\section{Composição química e efeito inibitório in vitro dos óleos essenciais das cascas dos frutos de três espécies de Citrus e do limoneno sobre o crescimento micelial de Sclerotinia sclerotiorum}

\begin{abstract}
Resumo
Óleos essenciais de plantas aromáticas e medicinais geralmente exibem uma gama diversificada de atividades biológicas, pois possuem vários constituintes ativos que atuam por meio de vários mecanismos de ação. Os óleos essenciais das cascas de Citrus têm uma variedade impressionante de usos em alimentos, medicamentos entre várias outras aplicações. Os óleos essenciais (OE) de Citrus reticulata, $C$. sinenses e $C$. deliciosa foram extraídos das cascas dos frutos e analisados por CG-EM. O limoneno foi o constituinte majoritário encontrado nos óleos essenciais avaliados, nas concentrações de $98,54 \%$, 91,65\% e 91,27\% para C. sinensis, C. reticulata e C. deliciosa, respectivamente. Os maiores potenciais de inibição do crescimento micelial foi observado na dose de $300 \mu \mathrm{L}$ dos óleos. Os óleos de Citrus inibiram em $82,91 \%$ (C. deliciosa), 65,82\% (C. sinensis) e 63,46\% (C. reticulata) o crescimento do fungo. A atividade anti-Sclerotinia sclerotiorum do limoneno $90 \%$ puro e em diferentes doses $(20,50,100,200$ e $300 \mu \mathrm{L})$ foi também investigada e este monoterpeno demonstrou-se altamente ativo inibindo $100 \%$ o crescimento do fungo inclusive nas doses de 200 e $300 \mu \mathrm{L}$. Este é o primeiro relato sobre o efeito inibitório in vitro dos óleos essenciais destas três espécies de Citrus e os resultados deste estudo mostram que existe uma boa perspectiva de uso destes produtos naturais experimentalmente para controlar o S. sclerotiorum tanto em condições de estufa como em condições de campo.
\end{abstract}

Palavras-chave: Citrus reticulata, Citrus sinensis, Citrus deliciosa, podridão branca, limoneno, mofo branco. 


\section{Introduction}

The fungus Sclerotinia sclerotiorum, one of the most common pathogens, causes white mold and severe damage to several economically important cultures, such as beans and soybeans, thus, making Brazilian producers face great losses (Haddad et al., 2017). Controlling this disease with the use of chemicals is not only ineffective but also contradictory, since it does not follow the current tendency which searches for ecologically balanced and stable agricultural systems that do not release toxic waste (Milan et al., 2015).

White mold development is favored by certain conditions, such as high humidity and low/moderate temperatures. It may be controlled, mainly by fungicide application, which depends on several factors, such as soil inoculum density, phases of the epidemic, fungicide coverage of plants, number of pulverization steps, fungitoxicity doses, application time, volume and equipment, plant spacing, besides disease incidence and severity (Silva et al., 2017).

Regarding the fungus $S$. sclerotiorum, it develops resistant structures called sclerotia, which can survive in soil for several years even if there are no hosts (Silva et al., 2011). Sclerotia play a very important role in the life cycle of this phytopathogen, since they are precursors of apothecia, where ascospores are formed. In ideal conditions, ascospores may infect cultures and start infection by spores (Silva et al., 2011). In fact, several factors, such as nutrients of the substrate in which sclerotia develop, sclerotium age and environmental factors (humidity, temperature, light, soil $\mathrm{pH}$, soil aeration and burial depth), influence germination of this fungus sclerotia (Gomes et al., 2017).

Regarding problems caused by white mold, several studies have shown that natural products have promising activities, for instance, the bioactivity of essential oils (EO) against different phytopathogens, such as $S$. sclerotiorum (Al-Taisan et al., 2014). EO, mainly the ones extracted from Citrus species, exhibit a broad spectrum of biological activity and activity against Gram-positive and Gram-negative bacteria, yeast and mycotoxigenic and deteriorating filamentous fungi (Qadir et al., 2018).

In order to keep carrying out studies of determination of chemical composition of EO and their activity against white mold (Valadares et al., 2018) and considering the interest of our research group in EO from Citrus species (Estevam et al., 2016; Lemes et al., 2018), the study reported by this paper addresses the chemical composition of EO extracted from Citrus reticulata, $C$. sinensis and C. deliciosa fruit peel (Figure 1) and their in vitro inhibitory effect on mycelial growth of $S$. sclerotiorum.

\section{Material and Methods}

\subsection{Plant material}

Plant material was collected in Rio Verde (1799.4'63.2”S and $\left.51^{\circ} 05.2^{\prime} 44.6^{\prime} \mathrm{W}\right)$, a city located in Goiás state, Brazil, on January 2nd, 2018, at 9 a.m. The plant was identified by the botanist Luzia Francisca de Souza and voucher specimens of Citrus reticulata, Citrus sinensis and Citrus deliciosa were deposited in the herbarium in Rio Verde, at the Instituto Federal Goiano (IFGOIANO) under identification number \#4488, \#4489 and \#4490, respectively.

\subsection{Essential oil extraction}

EO from Citrus were extracted from fruit peel by hydrodistillation - performed in triplicate - in a Clevenger-type apparatus for $2 \mathrm{~h}$. The plant material was divided into three 500 -g samples and $500 \mathrm{~mL}$ distilled water was added to each sample. After manual collection of EO, water traces which remained in the oil were removed with anhydrous sodium sulfate. The next step was filtration. EO were then stored in an amber bottle and kept in a refrigerator at $4{ }^{\circ} \mathrm{C}$ until analysis. Calculation of EO yield was based on the weight of the fruit peel; it was expressed as the average of the triplicate analyses.

\subsection{Chemical analysis of essential oils}

The analysis of the chemical constituents of EO from the fruit peel of both plants was carried out using a Shimadzu QP 5000 GC gas chromatograph equipped with a fused-silica capillary column OPTIMA-5 $(30 \mathrm{~m} \times 0.25 \mathrm{~mm} \times 0.250 \mu \mathrm{m})$ and a helium carrier gas $(\mathrm{He})$ detector and electron impact ionization (EI) $(70 \mathrm{eV})$ (Table 1). The initial temperature was maintained at $150{ }^{\circ} \mathrm{C}$ for $3.0 \mathrm{~min}$, programmed to $280^{\circ} \mathrm{C}$ at $10^{\circ} \mathrm{C} / \mathrm{min}$ and left at this temperature for an additional $4.0 \mathrm{~min}$. The others parameters were as follows: injector temperature $250^{\circ} \mathrm{C}$, detector temperature $280^{\circ} \mathrm{C}$, injection pressure $100 \mathrm{kPa}$, due to Split 30, mass spectrometer detection range 43-500 m/z, start time (cut team solvent) $2.0 \mathrm{~min}$ and flow $1.1 \mathrm{~mL} / \mathrm{min}$. The identification of oil components was based on the linear retention index (Kovats Index $-\mathrm{KI}$ ) calculated with respect to the retention times of a homologous series of $n$-alkanes (C-14 to C-26, C-28 and $\mathrm{C}-30)$ and the fragmentation pattern observed in the mass spectra and by comparing these values with the literature data (Adams, 2007) and NIST/EPA/NIH Mass Spectral Library (NIST 08).

\subsection{Antifungal assay}

The isolate of Sclerotinia sclerotiorum Ss12 (BRM 29673) was provided by the Embrapa Arroz e Feijão, whose headquarters is in Santo Antônio de Goiás, GO, Brazil. Assays were carried out in the agricultural microbiology laboratory at IF Goiano - Campus Rio Verde and the antifungal activity of EO from fruit peel of Citrus species

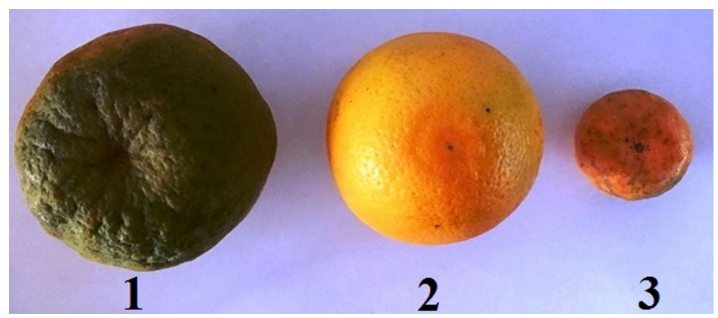

Figure 1. Citrus reticulata (1), Citrus sinensis (2) and Citrus deliciosa (3). 
was evaluated by the disc-diffusion method described by Xavier et al. (2016) - with modifications - whose EO doses were $20 \mu \mathrm{L}$ (diluted in $480 \mu \mathrm{L}$ of $\mathrm{H}_{2} \mathrm{O}+100 \mu \mathrm{L}$ of Tween), $50 \mu \mathrm{L}$ (diluted in $450 \mu \mathrm{L}$ of $\mathrm{H}_{2} \mathrm{O}+100 \mu \mathrm{L}$ of Tween), $100 \mu \mathrm{L}$ (diluted in $400 \mu \mathrm{L}$ of $\mathrm{H}_{2} \mathrm{O}+100 \mu \mathrm{L}$ of Tween), $200 \mu \mathrm{L}$ (diluted in $300 \mu \mathrm{L}$ of $\mathrm{H}_{2} \mathrm{O}+100 \mu \mathrm{L}$ of Tween ) and $300 \mu \mathrm{L}$ (diluted in $200 \mu \mathrm{L}$ of $\mathrm{H}_{2} \mathrm{O}+100 \mu \mathrm{L}$ of Tween) for three Citrus species, respectively (Table 2). The anti-Sclerotinia sclerotiorum activity of limonene alone and at the same doses of EO $(20-300 \mu \mathrm{L}$; with dilutions equal to those of the EO) was also evaluated. In the analyses, limonene ( $90 \%$ purity) was purchased from Sigma-Aldrich $^{\circledR}$, Castle Hill, NSW, Australia. Negative controls were dishes with no addition of EO (witness) whereas the positive control was the fungicide Frowncide $500 \mathrm{SC}$, at $10 \mu \mathrm{g} / \mathrm{mL}$ of active ingredient. Petri dishes were sterilized and prepared with PDA culture medium. After medium solidification, EO, at previously mentioned doses, were added and smeared on the surface of the dish with the help of a Drigalski spatula. Afterwards, $5 \mathrm{~mm}$ diameter PDA medium discs with 10-day-old mycelium were placed in the center of the dishes. Then, they were incubated at $28 \pm 2{ }^{\circ} \mathrm{C}$ and mycelial growth was measured daily, up to full growth of the fungus on control dishes. The treatment was carried out in quadruplicate and the experimental design was thoroughly randomized. Data were submitted to the analysis of variance (ANOVA) and resulting means of all treatments were evaluated by the Scott-Knott test at $5 \%$ significance by the ASSISTAT software.

Percentage of inhibition of mycelial growth (IMG) was calculated by the following Formula (1):

$$
\operatorname{IMG}(\%)=\frac{(\text { control growth }- \text { treatment growth })}{\text { control growth }} \times 100
$$

\section{Results and Discussion}

Extraction of EO from Citrus sinensis, C. reticulata and $C$. deliciosa fruit peel yielded $0.8 \%, 0.6 \%$ and $0.7 \%$, respectively. GC-MS identified four chemical constituents of EO from C. sinensis (total was $99.80 \%$ ), four from C. reticulata (total was $98.88 \%$ ) and eleven from C. deliciosa (total was 99.14\%). The major constituent of the three EO under analysis was limonene, which was found at the following concentrations: $98.54 \%$ (C. sinensis), $91.65 \%$ (C. reticulata) and $91.27 \%$ (C. deliciosa). Components,

Table 1. Chemical composition of EO from Citrus sinensis, C. reticulata and C. deliciosa fruit peel.

\begin{tabular}{|c|c|c|c|c|c|}
\hline \multirow{2}{*}{ Compounds } & \multicolumn{2}{|c|}{ RI } & \multicolumn{3}{|c|}{ RA\% } \\
\hline & Literature & Calculated & C. sinensis & C. reticulata & C. deliciosa \\
\hline Tricyclene & 921 & 921 & 0.25 & - & - \\
\hline$\alpha$-Thujene & 924 & 923 & - & 0.13 & - \\
\hline Sabinene & 969 & 968 & - & - & 1.06 \\
\hline$\beta$-Pinene & 974 & 976 & 0.74 & 0.93 & 1.27 \\
\hline$n$-Octanal & 998 & 996 & - & - & 0.19 \\
\hline$\delta$-2-Carene & 1001 & 1000 & 0.27 & - & - \\
\hline Limonene & 1024 & 1023 & 98.54 & 91.65 & 91.27 \\
\hline (E)- $\beta$-Ocimene & 1044 & 1044 & - & - & 0.09 \\
\hline$\gamma$-Terpinene & 1054 & 1055 & - & 6.17 & 0.12 \\
\hline Linalool & 1095 & 1097 & - & - & 4.04 \\
\hline 3-Thujanol & 1164 & 1164 & - & - & 0.28 \\
\hline$\alpha$-Terpineol & 1186 & 1185 & - & - & 0.37 \\
\hline cis-Cadina-1(6),4-diene & 1461 & 1461 & - & - & 0.39 \\
\hline \multirow[t]{2}{*}{$\beta$-Macrocarpene } & 1499 & 1498 & - & - & 0.06 \\
\hline & Total & & 99.80 & 98.88 & 99.14 \\
\hline
\end{tabular}

RI: Retention index; RA\%: relative area.

Table 2. In vitro antifungal activity of EO from Citrus and limonene against S. sclerotiorum.

\begin{tabular}{|c|c|c|c|c|c|}
\hline \multirow{2}{*}{ FUNGI } & \multirow{2}{*}{$\begin{array}{c}\text { Essential oils } \\
\mu \mathrm{L}(\text { doses })\end{array}$} & \multicolumn{4}{|c|}{ Inhibition of mycelial growth (\%) } \\
\hline & & C.sinensis & C. deliciosa & C. reticulata & Limonene \\
\hline Sclerotinia & N.C & $0 \mathrm{a}$ & $0 \mathrm{a}$ & $0 \mathrm{a}$ & $0 \mathrm{a}$ \\
\hline sclerotiorum & 20 & $2.16 \mathrm{bA}$ & $11.00 \mathrm{bA}$ & $50.69 \mathrm{bB}$ & $2.21 b$ \\
\hline & 50 & $7.47 \mathrm{bA}$ & $12.77 \mathrm{bA}$ & $51.67 \mathrm{bB}$ & $3.48 b$ \\
\hline & 100 & $14.42 \mathrm{bcA}$ & $26.13 \mathrm{bA}$ & $52.06 \mathrm{bB}$ & $43.03 \mathrm{c}$ \\
\hline & 200 & $49.71 \mathrm{bcA}$ & $26.72 \mathrm{bA}$ & $52.06 \mathrm{bA}$ & $100.00 \mathrm{~d}$ \\
\hline & 300 & $65.82 \mathrm{cA}$ & $82.91 \mathrm{cA}$ & $63.46 \mathrm{bA}$ & $100.00 \mathrm{~d}$ \\
\hline
\end{tabular}

N.C: negative control. Different small letters show differences among concentrations. Different capital letters show differences among Citrus species. Positive control (Frowncide 500 SC) inhibited $100 \%$ of fungus development. Limonene (90\% purity) alone without dilution also showed $100 \%$ potential of inhibition. 
retention indexes and relative percentages $(\%)$ are shown in Table 1.

Comparison between compounds identified and listed in Table 1 and others reported by similar studies of Citrus species showed that compounds of EO from $C$. sinensis and $C$. reticulata fruit peel had little chemical variability, i. e., only four constituents were identified in each oil. However, these oils exhibited a very high content of the monoterpene limonene, which was found at concentrations of $98.54 \%$ in C. sinensis oil and $91.65 \%$ in C. reticulata oil. Kamal et al. (2011) reported higher chemical variability in compounds of fruit peel of the same species, but lower concentrations of limonene, by comparison with findings of this study. Concerning the chemical composition of C. deliciosa oil, this study found high chemical variability, since eleven chemical constituents were identified in EO from $C$. deliciosa fruit peel. Limonene was also identified at significant concentration $-99.14 \%-$, which is higher than the one reported by El-hawary et al. (2013), who found $77.55 \%$ in EO from fruit peel. In this study, the chemical composition was also similar to the one that was previously reported in the case of EO from twenty Citrus species found in China. Limonene, $\alpha$-pinene, sabinene and terpinene were the characteristic compounds of metabolic profiles of all Citrus under evaluation (Jing et al., 2015).

In vitro antifungal activity of $\mathrm{EO}$ from $C$. sinensis, C. reticulata and $C$. deliciosa fruit peel was evaluated against the phytopathogenic fungus Sclerotinia sclerotiorum. Percentages of inhibition of mycelial growth (IMG) of EO from Citrus fruit peel are shown in Table 2.

The highest inhibitory potential against mycelial growth of the fungus $S$. sclerotiorum exhibited by oils under study was found when the oil dose was $300 \mu \mathrm{L}$. It inhibited $82.91 \%, 65.82 \%$ and $63.46 \%$ in the cases of EO from $C$. deliciosa, $C$. sinensis and $C$. reticulata, respectively (Table 2). It should be highlighted that all three EO from these three Citrus species, at the highest concentration under investigation, inhibited more than $50 \%$ of fungal growth. In addition, it is worth mentioning that EO from C. deliciosa fruit peel were the most active ones, a fact that may be explained by the high chemical variability of their compounds, which may act synergically and increase their biological activity (Sriwattanachai et al., 2018).

The antifungal activity of EO from Citrus found by this study may be related to the high concentration of the chemical constituent limonene, whose antifungal activity has been widely described in the literature. Chee et al. (2009) reported the promising activity of this monoterpene against the fungus Trichophyton rubrum. Hamdani et al. (2015) studied EO of four Citrus species and reported their potential in the biological control of phytopathogens, such as Fusarium oxysporum, Penicelium sp., Alternaria sp. and Fusarium sp.. They also highlighted the high concentration of limonene in the oils under study.

Special attention was given to the major constituent limonene. As a result, in this study, the anti-Sclerotinia sclerotiorum activity of this $90 \%$ pure monoterpene and at doses of 20, 50, 100, 200 and $300 \mu \mathrm{L}$ (with dilutions) was also investigated (Table 2). At all doses under evaluation, total inhibition of white mold occurred at 200 and $300 \mu \mathrm{L}$, thus representing $100 \%$ of inhibition of mycelial growth. When limonene ( $90 \%$ pure) was tested individually, it inhibited S. sclerotiorum growth in $100 \%$. It should be highlighted that limonene has already been identified at high concentrations in EO extracted from several Citrus species. This monoterpene - in its pure form - exhibited promising antifungal activity against other phytopathogenic fungi, such as Aspergillus niger, Phytophthora digitatum, Rhizoctonia solani, Fusarium oxysporum and Fusarium verticillioides, even against $S$. sclerotiorum itself(Jing et al., 2014; Ma et al., 2015). In addition, the therapeutic effects of limonene, such as anti-inflammatory, antioxidant, antinociceptive, anticancer, antidiabetic, antihyperalgesic, antiviral and gastroprotective ones, have been deeply studied (Vieira et al., 2018).

The mechanism of action of EO which exhibit some kind of biological activity is not very clear. Many studies suggest that cell membranes of microorganisms are the targets of bioactive volatile compounds since EO are complex mixtures of apolar molecules that bestow them high hydrophobicity. Therefore, EO cause degradation of the cell wall, disruption of cytoplasmic membrane, cytoplasmic leakage, cell lysis and, eventually, cell death (Jing et al., 2014). As a result, EO from Citrus deserve the distinction they have got lately, as well as their broad applicability to several areas, such as chemical, pharmaceutical, food and agronomical ones (Palazzolo et al., 2013).

\section{Conclusion}

In short, EO extracted from Citrus sinensis, C. reticulata and $C$. deliciosa fruit peel exhibit antifungal activity against the phytopathogen Sclerotinia sclerotiorum by inhibiting fungal growth in about $50 \%$ at $300 \mu \mathrm{L}$. The monoterpene limonene was the chemical constituent that was identified at high concentration in EO from Citrus under investigation. When limonene (90\% pure) was tested in its isolated form and at doses under evaluation (200 and $300 \mu \mathrm{L}-$ with dilutions), its high activity against white mold was proven (inhibition of $100 \%$ ). In addition, the antifungal activity of EO from Citrus species may result from synergism among the compounds that constitute the oils. Results of this study show that there is good prospect of using these EO from Citrus species experimentally to control phytopathogens in both greenhouse and field conditions. In sum, the monoterpene limonene proved to be an excellent natural alterative for the control of $S$. sclerotiorum.

\section{Acknowledgements}

The authors are grateful to FAPEG, CNPq, CAPES and IF GOIANO - Campus Rio Verde for their financial support.

\section{References}

ADAMS, R.P., 2007. In identification of essential oil components by gas chromatography/quadrupole mass spectroscopy. 4th ed. Carol Stream: Allured Publishing Corporation, 804 p. 
AL-TAISAN, W.A., BAHKALI, A.H., M. ELGORBA, A. and A. EL-METW, M., 2014. Effective Influence of Essential Oils and Microelements against Sclerotinia sclerotiorum. International Journal of Pharmacology, vol. 10, no. 5, pp. 275-281. http:// dx.doi.org/10.3923/ijp.2014.275.281.

CHEE, H.Y., KIM, H. and LEE, M.H., 2009. In vitro antifungal activity of limonene against Trichophyton rubrum. Mycobiology, vol. 37, no. 3, pp. 243-246. http://dx.doi.org/10.4489/ MYCO.2009.37.3.243. PMid:23983542.

EL-HAWARY, S.S., TAHA, K.F., ABDEL-MONEM, A.R., KIRILLOS, F.N. and MOHAMED, A.A., 2013. Chemical composition and biological activities of peels and leaves essential oils of four cultivars of Citrus deliciosa var. tangarina. American Journal of Essential Oils and Natural Products, vol. 1, no. 2, pp. 1-6.

ESTEVAM, E.B.B., MIRANDA, M.L.D., ALVES, J.M., B. EGEA, M., PEREIRA, P.S., MARTINS, C.H.G., R. ESPERANDIM, V., MAGAlHÃES, L.G., BOLELA, A.C., CAZAL, C.M., SOUZA, A.F. and ALVES, C.C.F., 2016. Composição química e atividades biológicas dos óleos essenciais das folhas frescas de Citrus limonia Osbeck e Citrus latifolia Tanaka (Rutaceae). Revista Virtual de Química, vol. 8, no. 6, pp. 1842-1854. http:// dx.doi.org/10.21577/1984-6835.20160124.

GOMES, R.S.S., ARAÚJO, A.E., NASCIMENTO, L.C., FEITOSA, E.D.A. and DEMARTELAERE, A.C.F., 2017. Caracterização da Sclerotinia sclerotiorum, transmissão e qualidade fisiológica em sementes de algodoeiro. Acta Iguazu, vol. 6, no. 4, pp. 105-113.

HADDAD, P.E., LEITE, L.G., LUCON, C.M.M. and HARAKAVA, R., 2017. Selection of Trichoderma spp. strains for the control of Sclerotinia sclerotiorum in soybean. Pesquisa Agropecuária Brasileira, vol. 52, no. 12, pp. 1140-1148. http:// dx.doi.org/10.1590/s0100-204x2017001200002.

HAMDANI, F.Z., ALLEM, R., MEZIANE, M., SETTI, B., ALI, A.S. and BOURAI, M., 2015. Chemical composition and antifungal activity of essential oils of Algerian citrus. African Journal of Biotechnology, vol. 14, no. 12, pp. 1048-1055. http:// dx.doi.org/10.5897/AJB2013.12140.

JING, L., LEI, Z., LI, L., XIE, R., XI, W., GUAN, Y., SUMNER, L.W. and ZHOU, Z., 2014. Antifungal activity of Citrus essential oils. Journal of Agricultural and Food Chemistry, vol. 62, no. 14, pp. 3011-3033. http://dx.doi.org/10.1021/jf5006148. PMid:24628448.

JING, L., LEI, Z., ZHANG, G., PILON, A.C., HUHMAN, D.V., XIE, R., XI, W., ZHOU, Z. and SUMNER, L.W., 2015. Metabolite profiles of essential oils in citrus peels and their taxonomic implications. Metabolomics, vol. 11, no. 4, pp. 952963. http://dx.doi.org/10.1007/s11306-014-0751-x.

KAMAL, G.M., ANWAR, F., HUSSAIN, A.I., SARRI, N. and ASHRAF, M.Y., 2011. Yield and chemical composition of Citrus essential oils as affected by drying pretreatment of peels. International Food Research Journal, vol. 18, no. 4, pp. 1275-1282.

LEMES, R.S., ALVES, C.C.F., ESTEVAM, E.B.B., SANTIAGO, M.B., MARTINS, C.H.G., SANTOS, T.C.L., CROTTI, A.E.M. and MIRANDA, M.L.D., 2018. Chemical composition and antibacterial activity of essential oils from Citrus aurantifolia leaves and fruit peel against oral pathogenic bacteria. Annals of the Brazilian Academy of Sciences, vol. 90, no. 2, pp. 1285-1292. http:// dx.doi.org/10.1590/0001-3765201820170847. PMid:29898096.
MA, B., BAN, X., HUANG, B.O., HE, J., TIAN, J., ZENG, H., CHEN, Y. and WANG, Y., 2015. Interference and mechanism of dill seed essential oil and contribution of carvone and limonene in preventing sclerotia rot of rapeseed. PLoS One, vol. 10, no. 7, pp. e0131733. http://dx.doi.org/10.1371/journal.pone.0131733. PMid:26133771.

MILAN, M.D., BARROSO, F.M., MELLO, S.C.M., ARAÚJO, M.S. and CARVALHO, D.D.C., 2015. Regimes de luz na produção de conídios de Trichoderma harzianum para controle do mofo branco em feijoeiro. Pesquisa Agropecuária Tropical, vol. 45, no. 4, pp. 434-439. http://dx.doi.org/10.1590/1983-40632015v4537755.

PALAZZOLO, E., LAUDICINA, V.A. and GERMANÀ, M.A., 2013. Current and potential use of Citrus essential oils. Current Organic Chemistry, vol. 17, no. 1, pp. 3042-3049. http://dx.doi. org/10.2174/13852728113179990122.

QADIR, R., ANWAR, F., MEHMOOD, T., SHAHID, M. and ZAHOOR, S., 2018. Variations in chemical composition, antimicrobial and haemolytic activities of peel essential oils from three local Citrus cultivars. Pure and Applied Biology, vol. 7, no. 1, pp. 282-291. http://dx.doi.org/10.19045/bspab.2018.70034.

SILVA, F.F., CASTRO, E.M., MOREIRA, S.I., FERREIRA, T.C., LIMA, A.E. and ALVES, E., 2017. Emergência e análise ultraestrutural de plântulas de soja inoculadas com Sclerotinia sclerotiorum sob efeito da aplicação de Trichoderma harzianum. Summa Phytopathologica, vol. 43, no. 1, pp. 41-45. http://dx.doi. org/10.1590/0100-5405/2212.

SILVA, F.P.M., GAVASSONI, W.L., BACCHI, L.M.A. and GARCEZ, F.R., 2011. Germinação carpogênica de Sclerotinia sclerotiorum sob diferentes resíduos e extratos de plantas cultivadas. Summa Phytopathologica, vol. 37, no. 3, pp. 131-136. http:// dx.doi.org/10.1590/S0100-54052011000300009.

SRIWATTANACHAI, S., SADIQ, M.B. and ANAL, A.K., 2018. Synergistic antifungal effects of thyme essential oil and Lactobacillus plantarum cell-free supernatant against Penicillium spp. and in situ effects. Journal of Food Processing and Preservation, vol. 42, no. 1, pp. e-13400. http://dx.doi.org/10.1111/jfpp.13400.

VALADARES, A.C.F., ALVES, C.C.F., ALVES, J.M., DEUS, I.P.B., OLIVEIRA FILHO, J.G., SANTOS, T.C.L., DIAS, H.J., CROTTI, A.E.M. and MIRANDA, M.L.D., 2018. Essential oils from Piper aduncum inflorescences and leaves: chemical composition and antifungal activity against Sclerotinia sclerotiorum. Anais da Academia Brasileira de Ciências, vol. 90, no. 3, pp. 2691-2699. http://dx.doi.org/10.1590/0001-3765201820180033. PMid:30304214

VIEIRA, A.J., BESERRA, F.P., SOUZA, M.C., TOTTI, B.M. and ROZZA, A.L., 2018. Limonene: aroma of innovation in health and disease. Chemico-Biological Interactions, vol. 283, no. 1, pp. 97-106. http://dx.doi.org/10.1016/j.cbi.2018.02.007. PMid:29427589.

XAVIER, M.N., ALVES, J.M., CARNEIRO, N.S., SOUCHIE, E.L., SILVA, E.A.J., MARTINS, C.H.G., AMBROSIO, M.A.L.V., EGEA, M.B., ALVES, C.C.F. and MIRANDA, M.L.D., 2016. Composição química do óleo essencial de Cardiopetalum calophyllum Schltdl. (Annonaceae) e suas atividades antioxidante, antibacteriana e antifúngica. Revista Virtual de Química, vol. 8, no. 5, pp. 1433-1448. 